Compl exati on of Amwith si ze-fracti onat ed soi I humi c aci ds

\begin{tabular}{|l|l|}
\hline 著者 & Nagao S., Aoyama M, Wat anabe A. , Tanaka T. \\
\hline 杂隹誌名 & $\begin{array}{l}\text { 年報 金沢大学環日本海域環境研究センター = } \\
\text { K I IET Kanazawa Uni ver si ty }\end{array}$ \\
\hline 巻 & 平成20年度 \\
\hline 号 & 2008 \\
\hline ページ & $70-70$ \\
\hline 発行年 & $2010-01-29$ \\
\hline URL & ht t p: //hdl . handl e. net /2297/30152 \\
\hline
\end{tabular}




\title{
Complexation of Am with size-fractionated soil humic acids
}

\author{
S. Nagao ${ }^{1}$, M. Aoyama ${ }^{2}$, A. Watanabe ${ }^{3}$, T. Tanaka ${ }^{4}$ \\ ${ }^{1}$ Faculty of Environmental Earth Science, Hokkaido University, \\ ${ }^{2}$ Faculty of Agriculture and Life Science, Hirosaki University, \\ ${ }^{3}$ Graduate school of Bioagricultural Sciences, Nagoya University, \\ ${ }^{4}$ Tokai Research and Development Center, Japan Atomic Energy Agency
}

Humic substances (humic and fulvic acids) are ubiquitous in nature and have many beneficial effects on soils and aquatic environments. They play important role in geochemical behavior of trace elements such as actinides from fallout and local sources in aquatic environments. Therefore, characteristics of actinides bound to humic and fulvic acids can yield information on the geochemical role of humic substances in the migration of actinides. In this study, the association properties of Am with humic substances were studied on the basis of structural feature of humic substances. We separated two humic acids ('HA': fluorescence-poor and higher molecular size fraction, 'FL': fluorescence-rich and lower molecular size fraction) with different structural features from humic acids prepared from three types of soils (andisol, entisol and buried andisol) by Sephadex G-25. The association experiments were carried out in a medium of $0.01 \mathrm{M} \mathrm{NaClO}_{4}$ solution at a humus concentration of $10 \mathrm{mg} / \mathrm{l}$ and $\mathrm{pH} 6-8$. After finishing the association experiments, ultrafiltration was used to size-fractionate Am in the humus solutions. Figure 1 shows molecular size distribution of Am in the presence of size-fractionated HAs. The dominant size fractions of $\mathrm{Am}$ in the presence of ' $\mathrm{HA}$ ' were $450 \mathrm{~nm}-100 \mathrm{k}$ Da (48-53\% for the andisol and entisol) and $100 \mathrm{k}-30 \mathrm{k} \mathrm{Da}$ ( $60 \%$ for the buried andisol). On the other hand, $43-51 \%$ of Am was presented in the size of 30-10k Da in the 'FL' HA solutions from three soil types. These results indicate that characteristics of size-fractionated humic acids are related association properties with Am.

Fig. 1 Size distribution of $\mathrm{Am}$ in the presence of HAs.

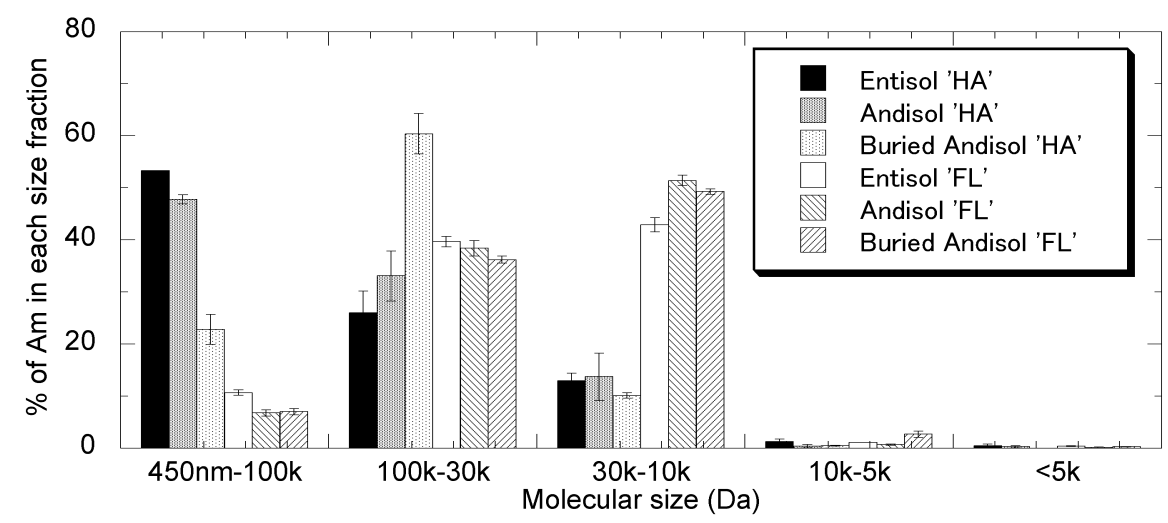

